\title{
Pharmacokinetics of Protein C and Antithrombin in the Fetal Lamb: A Model to Predict Human Neonatal Replacement Dosing
}

\author{
Marilyn J. Manco-Johnson ${ }^{a, b}$ Michele R. Hacker ${ }^{a, d}$ Linda J. Jacobson ${ }^{a, b}$ \\ William W. Hay, Jr. ${ }^{b, c}$ \\ ${ }^{a}$ Mountain States Regional Hemophilia and Thrombosis Center, ${ }^{b}$ Department of Pediatrics, and \\ 'Perinatal Research Center, University of Colorado Denver, Aurora, Colo., and d Department of Obstetrics \\ and Gynecology, Beth Israel Deaconess Medical Center, Harvard Medical School, Boston, Mass., USA
}

\section{Key Words}

Protein C · Antithrombin • Pharmacokinetics · Lamb •

Replacement protein

\begin{abstract}
Background: The preterm infant is at risk for consumptive coagulopathy and thrombosis due to late maturation of coagulation regulatory proteins. Replacement proteins are available, but neonatal pharmacokinetic data are lacking. Objective: The objective was to determine the pharmacokinetic properties of antithrombin (AT) and protein C (PC) in order to provide data for estimating doses in human infants. Methods: A catheterized ovine model was used to determine pharmacokinetic properties of AT and PC, including plasma recovery, volume of distribution $\left(\mathrm{V}_{\mathrm{d}}\right)$, clearance $(\mathrm{Cl})$ and half-life $\left(t_{1} / 2\right)$, in the fetal lamb relative to the ewe. $\boldsymbol{R e}$ sults: AT studies showed statistically significant differences between ewes and fetuses in recovery $(p<0.0001), V_{d}(p=$ $0.0002)$ and $\mathrm{Cl}(p<0.0001)$. The $A T t_{1 / 2}$ was significantly shortened among fetuses $(5.55 \mathrm{~h}, 95 \% \mathrm{Cl}: 4.01-7.08)$ compared to ewes $\left(18.7 \mathrm{~h}, 95 \% \mathrm{Cl}\right.$ : 11.6-25.8). PC recovery $(p<0.0001), \mathrm{V}_{d}$ $(p<0.0001)$ and $\mathrm{Cl}(\mathrm{p}=0.004)$ differed significantly between ewes and singleton fetuses as did the $\mathrm{t}_{1 / 2}: 3.86 \mathrm{~h}(95 \% \mathrm{Cl}: 3.35$ 4.36) and $11.9 \mathrm{~h}(95 \% \mathrm{Cl}: 10.9-12.9)$ in the singletons and ewes, respectively. All PC parameters were significantly different for twins compared to ewes. Conclusions: AT and PC
\end{abstract}

show decreased recovery and $t_{1 / 2}$ in the fetal lamb. These data can be used to estimate dosing for human neonates in comparison with human adult dosing recommendations.

Copyright $\odot 2008$ S. Karger AG, Basel

\section{Introduction}

Newborn infants, particularly sick preterm neonates, are at increased risk of disseminated intravascular coagulation (DIC) and catheter-related thrombosis [1,2]. In part, the increased rate of these prothrombotic syndromes during the perinatal period is attributed to delayed fetal and neonatal physiological maturation of the coagulation-regulatory proteins antithrombin (AT) and protein $\mathrm{C}(\mathrm{PC})[3,4]$. Further reductions in plasma levels of PC and AT have been determined in sick infants $[5,6]$. Deficiencies in coagulation-regulatory proteins are compounded in neonates with thrombosis because standard anticoagulation using unfractionated and low-molecular-weight heparin is often difficult to achieve in newborn infants secondary to very low levels of AT $[7,8]$.

Infants with severe genetic AT deficiency have developed life-threatening thrombosis during the perinatal period [9-11]. Acquired AT deficiency causes severe thrombosis in infants undergoing cardiopulmonary bypass or extracorporeal membrane oxygenation $[12,13]$. A

\section{KARGER}

๑) 2008 S. Karger AG, Basel

Fax +41613061234 E-Mail karger@karger.ch www.karger.com www.karger.com/neo
Marilyn J. Manco-Johnson

Mountain States Regional Hemophilia and Thrombosis Center

PO Box 6507, MS F416

Aurora, CO 80045-0507 (USA)

Tel. +1 303724 0365, Fax +1 303724 0947, E-Mail marilyn.manco-johnson@uchsc.edu 
knockout mouse model of AT deficiency shows embryonic lethality by 16.5 gestational days [14]. The plasma half-life $\left(t_{1 / 2}\right)$ of AT has been reported at $59 \mathrm{~h}$ in stable ATdeficient adults [15]. This long $t_{1 / 2}$ supports the feasibility of intravenous protein replacement, based on clinical indications. Concentrates of human plasma-derived, highly purified, viral-inactivated AT are licensed and have been used to treat adults, children and neonates with genetic deficiencies around surgery, childbirth and episodes of thrombosis [9-11, 15-17]. In addition, AT concentrate has been given to infants and children with acquired deficiencies secondary to sepsis, cardiopulmonary bypass surgery, DIC, chemotherapy with L-asparaginase and liver transplantation [12, 17-21]. Human infants have a mean plasma concentration of AT of $50 \mathrm{U} / \mathrm{dl}$ at term birth and reach the adult level of $100 \mathrm{U} / \mathrm{dl}$ by 6 months [3, $4,6,22]$. Stressed preterm infants have levels of AT as low as $10 \mathrm{U} / \mathrm{ml}[6,23]$.

Infants with homozygous or compound heterozygous genetic deficiencies of PC present in the neonatal period with purpura fulminans, DIC and large-vessel thrombosis [24-26]. The $t_{1 / 2}$ of PC in plasma has been reported at $6-8 \mathrm{~h}[27,28]$. A concentrate of human-plasma-derived, highly purified, viral inactivated $\mathrm{PC}$ has been licensed in Europe and the USA [27-29]. PC concentrate has been used in patients with heterozygous genetic deficiencies around childbirth [27] and in infants and children with homozygous or compound heterozygous genetic deficiencies during episodes of purpura fulminans, DIC and large-vessel thrombosis as well as for the prophylaxis of these lesions $[28,29]$. The mean plasma concentration of PC in healthy term infants is $40 \mathrm{U} / \mathrm{dl}$ and does not achieve adult levels until later childhood, and possibly puberty $[3-6,30]$. Very low levels of PC, less than $10 \mathrm{U} / \mathrm{dl}$, have been reported in sick preterm infants and appear to convey an increased risk of thrombosis $[5,6]$.

Replacement therapies may be beneficial in sick neonates with very low levels of AT and PC. However, little is known regarding the pharmacokinetics of these proteins in the preterm and term infant. Because available replacement concentrates of $\mathrm{AT}$ and $\mathrm{PC}$ are derived from pooled human plasma, it is not ethical to infuse them into stable human infants for the purposes of pharmacokinetic research. We chose a fetal ovine (lamb) model to compare plasma recovery and elimination following infusion of replacement concentrates of these proteins in comparison to ewes. Previous studies of coagulation proteins in fetal and adult sheep (ewes) in our lab have shown good comparability with human (preterm and term neonate, child, adult) data [31-33].

\section{Methods}

\section{Preparation of the Animal Model}

Pregnant Columbia-Rambouillet sheep with known gestational age were operated on between 70 and 80 days of gestation to place maternal arterial sampling and venous infusion catheters or at approximately 120 days of gestation for placement of both maternal and fetal arterial sampling catheters and venous infusion catheters. At both times of gestation, surgery was performed using either of two anesthesia protocols: intravenous pentobarbital sedation $(15 \mathrm{mg} / \mathrm{kg})$ and spinal anesthesia (tetracaine $\mathrm{HCl}, 10$ $\mathrm{mg}$ in hypertonic glucose) or intramuscular acetylpromazine $(1 \mathrm{mg} / \mathrm{kg})$ with intravenous ketamine anesthesia $(12-15 \mathrm{mg} / \mathrm{kg}$ loading dose with $0.3-0.5 \mathrm{mg} / \mathrm{kg} / \mathrm{min}$ continuous infusion). Catheters for infusion and sampling were placed into fetal and maternal vessels using standard surgical procedures as previously described [31]. Fetal catheters included an arterial catheter for sampling inserted via the dorsal pedal artery and advanced to the lower abdominal aorta and a venous catheter for infusion inserted via the dorsal pedal saphenous vein and advanced into the lower abdominal vena cava. Maternal arterial (sampling) and venous (infusion) catheters were inserted into the maternal femoral artery and vein via a groin incision. All catheters were tunneled subcutaneously and kept within a plastic pouch attached to the maternal flank. The catheters were flushed daily to every other day with $0.9 \% \mathrm{wt} / \mathrm{vol} \mathrm{NaCl}$ in $\mathrm{H}_{2} \mathrm{O}$ that contained $30 \mathrm{U} / \mathrm{ml}$ sodium heparin. After surgery, the sheep were allowed to recover at least 4 days before study. All protocols were approved by the Animal Care and Use Committee of the University of Colorado Denver, which is accredited for laboratory animal use by the National Institutes of Health, the United States Department of Agriculture, and the American Association of Laboratory Animal Care.

\section{Laboratory Methods}

Plasma from healthy adult sheep was used to isolate ovine PC as previously described [32]. Ovine PC was used to raise polyclonal rabbit anti-ovine $\mathrm{PC}$ antibodies. An assay for ovine plasma PC concentration was established using the Laurell rocket technique as previously described [32]. Ovine plasma AT activity was determined using a chromogenic assay as previously described [31]. A Laurell immunoassay for human PC in ovine plasma was established using a polyclonal rabbit anti-human PC antibody. This assay did not detect ovine PC in a plasma pool prepared from 26 healthy adult male and female sheep. A similar assay for human AT in ovine plasma was established using a polyclonal rabbit anti-human AT antibody. This assay also failed to detect ovine AT in the ovine plasma pool described above.

Blood samples were collected from the ewe and her fetus on one or more occasions. The catheters were first cleared by removing $3 \mathrm{ml}$ of blood, and then $0.9-\mathrm{ml}$ blood samples were drawn into $0.1 \mathrm{ml}$ of $3.8 \%$ sodium citrate anticoagulant. The samples were centrifuged at $1,800 \mathrm{~g}$ for $20 \mathrm{~min}$ at $4^{\circ} \mathrm{C}$. Aliquots of plasma were subsequently frozen at $-70^{\circ} \mathrm{C}$ until the time of assay.

\section{Establishment of Normal Adult and Gestational Ovine}

Plasma PC Concentrations

Separate aliquots of frozen plasma were thawed for assay of PC and AT. A standard ovine plasma pool was prepared from 26 healthy nonpregnant adult sheep. Normal adult values for ovine $\mathrm{PC}$ and AT were derived from these individual plasma samples, 
Table 1. Pharmacokinetic calculations of AT and PC infusions

\begin{tabular}{|c|c|c|c|c|c|c|}
\hline & $t_{1 / 2}, h$ & $\mathrm{k}, \mathrm{h}^{-1}$ & $\mathrm{Cp}_{0}, \mathrm{U} / \mathrm{dl}$ & $\begin{array}{l}\text { Recovery } \\
\mathrm{U} / \mathrm{dl} \text { per } \mathrm{U} / \mathrm{kg}\end{array}$ & $\mathrm{V}_{\mathrm{d}}, \mathrm{dl} / \mathrm{kg}$ & $\mathrm{Cl}, \mathrm{dl} / \mathrm{kg} / \mathrm{h}$ \\
\hline \multicolumn{7}{|c|}{ Antithrombin } \\
\hline \multicolumn{7}{|c|}{ Ewes $(\mathrm{n}=3)$} \\
\hline Mean & 18.7 & 0.04 & 51.9 & 2.24 & 0.49 & 0.02 \\
\hline $\mathrm{SD}$ & & & 5.37 & 0.15 & 0.05 & 0.003 \\
\hline $95 \% \mathrm{CI}$ & $11.6-25.8$ & $0.02-0.05$ & & & & \\
\hline \multicolumn{7}{|c|}{ Fetuses $(n=4)$} \\
\hline Mean & 5.55 & 0.13 & 61.6 & 0.93 & 1.14 & 0.14 \\
\hline $\mathrm{SD}$ & & & 5.26 & 0.13 & 0.10 & 0.01 \\
\hline $95 \% \mathrm{CI}$ & $4.01-7.08$ & $0.09-0.16$ & & & & \\
\hline $\mathrm{p}^{1}$ & & & & $<0.0001$ & 0.0002 & $<0.0001$ \\
\hline \multicolumn{7}{|c|}{ Protein $C$} \\
\hline \multicolumn{7}{|c|}{ Ewes $(n=6)$} \\
\hline Mean & 11.9 & 0.06 & 89.6 & 3.08 & 0.33 & 0.02 \\
\hline $\mathrm{SD}$ & & & 20.8 & 0.28 & 0.03 & 0.003 \\
\hline $95 \% \mathrm{CI}$ & $10.9-12.9$ & $0.05-0.06$ & & & & \\
\hline \multicolumn{7}{|c|}{ Singleton fetuses $(n=4)$} \\
\hline Mean & 3.86 & 0.18 & 113.1 & 1.62 & 0.62 & 0.12 \\
\hline $\mathrm{SD}$ & & & 10.6 & 0.15 & 0.06 & 0.02 \\
\hline $95 \% \mathrm{CI}$ & $3.35-4.36$ & $0.16-0.20$ & & & & \\
\hline $\mathrm{p}^{1}$ & & & & $<0.0001$ & $<0.0001$ & 0.004 \\
\hline \multicolumn{7}{|c|}{ Twin fetuses $(n=6)$} \\
\hline Mean & 5.56 & 0.12 & 78.7 & 1.30 & 0.81 & 0.11 \\
\hline $\mathrm{SD}$ & & & 2.82 & 0.26 & 0.16 & 0.04 \\
\hline $95 \% \mathrm{CI}$ & $5.09-6.03$ & $0.11-0.14$ & & & & \\
\hline $\mathrm{p}^{1}$ & & & & 0.0008 & 0.002 & 0.003 \\
\hline
\end{tabular}

with the pool mean expressed as $1 \mathrm{U} / \mathrm{ml}$ as previously described [33]. Study samples were read against curves constructed using dilutions of the normal ovine pool.

\section{Conduct of Recovery and Half-Life Studies of PC and AT in} the Ewe and Fetal Lamb

AT or PC was infused with a syringe pump over $10 \mathrm{~min}$. Blood samples were removed at various times following the end of the infusion. Baseline samples were collected in duplicate at least 10 min apart and assayed for both ovine and human PC antigen or human AT antigen and total AT activity. Assays were performed in duplicate and reported as mean results.

Dosing for the ewe and the lamb was based upon pilot data and calculated to achieve similar peak plasma concentrations in the adult and fetus for comparison of plasma elimination curves. On different days, human plasma-derived AT concentrate (generously donated by the American Red Cross, Holland Laboratories, Silver Springs, Md., USA) was infused at a standard dose of $25 \mathrm{U} / \mathrm{kg}$ into the maternal ewe or $70 \mathrm{U} / \mathrm{kg}$ into her fetus. On separate occasions, human plasma-derived PC concentrate (generously donated by Baxter-Immuno, Vienna, Austria) was infused at doses of 25,30 or $50 \mathrm{U} / \mathrm{kg}$ into the maternal ewe or 70 or $71 \mathrm{U} / \mathrm{kg}$ into her fetus. If the ewe carried a twin gestation, each fetus was stud- ied on a separate day. Fetal weight was estimated from an intrauterine fetal growth chart that has been established in our research facility for the Columbia-Rambouillet ovine breed. This chart accounts for different fetal growth rates in singletons and twins.

\section{Data Analysis}

SAS 9.1.3 was used for all analyses. The fetal plasma volume was adjusted to account for the dilutional effect of the placental plasma volume based on a study in which red blood cells and plasma were separately labeled to determine the plasma volume of the fetus alone and the plasma volume of the fetoplacental unit [34]. Creasy et al. [34] used ovine fetuses of the same gestational age as the sheep in our study and reported that plasma volume was $72.4 \mathrm{ml} / \mathrm{kg}$ for the fetus alone and $89.9 \mathrm{ml} / \mathrm{kg}$ for the fetoplacental unit. Thus, all fetal AT and PC levels were increased by a factor of 1.24 .

A nonlinear mixed-effects model for one-compartment exponential decay was used to determine the $t_{1 / 2}$ of each protein in the maternal and fetal models separately. This model allowed us to account for unbalanced numbers of repeated measures, as well as the variability within and between sheep. Specifically, the model incorporated parameters for the random error around each mea- 
Fig. 1. Elimination of human AT in ewes and fetal lambs. Each solid line represents the plasma concentration of AT for a ewe that was administered a dose of $25 \mathrm{U} / \mathrm{kg}$. Each dashed line represents the plasma concentration of AT for a singleton fetus that was administered a dose of $70 \mathrm{U} / \mathrm{kg}$. The inset graph uses the same scheme to show the natural logarithm of the plasma concentration of AT.

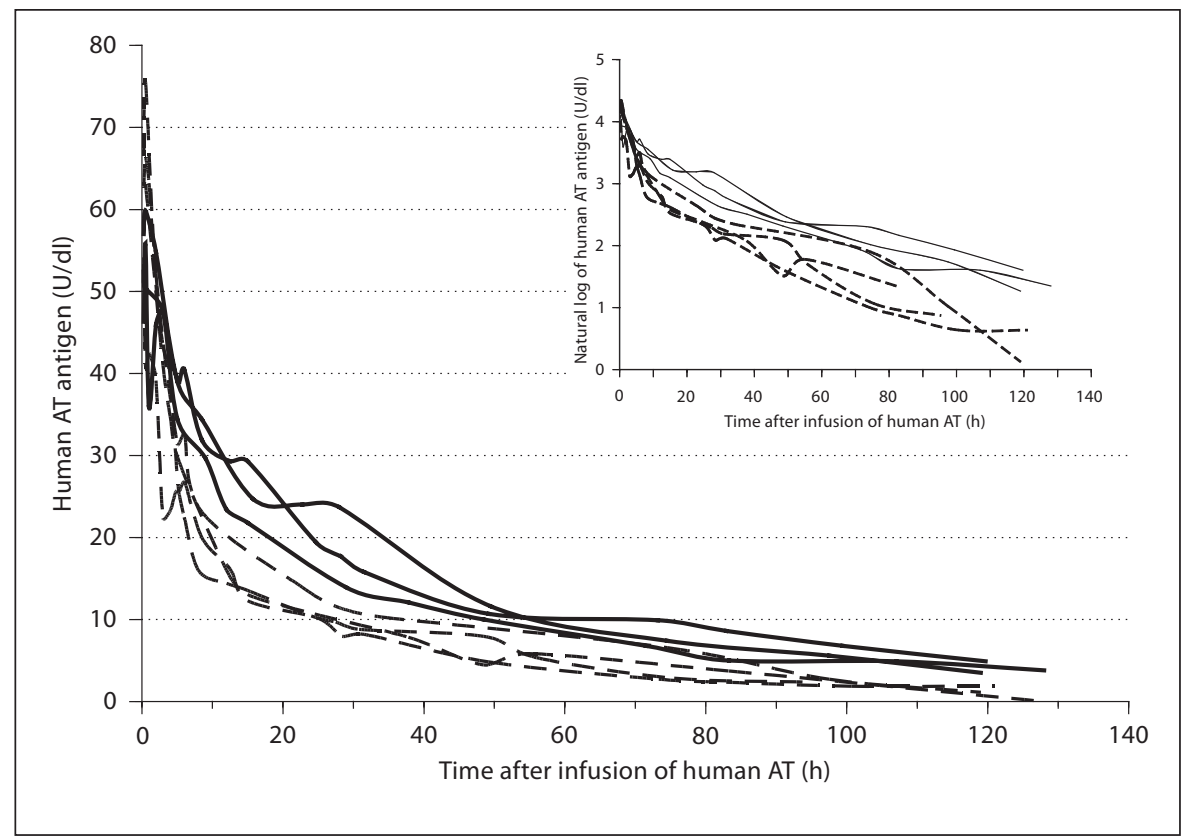

sured protein level, the random error around the elimination rate constant, and normal errors. Initial results indicated that the variance of the random error of the elimination rate constant was nearly zero, and the model fit the data better when this parameter was excluded. Half-lives and the rate elimination constant $(\mathrm{k})$ are reported in hours and hours ${ }^{-1}$, respectively, with a 95\% CI. Loglinear plots for PC and AT were constructed to illustrate that the data are consistent with a one-compartment model.

The other pharmacokinetic parameters were calculated using standard formulae [35]. The mean and standard deviation (SD) were calculated for each parameter and reported separately for ewes, singleton fetuses and twin fetuses. The standard deviations for the twins were adjusted for the lack of independence between siblings using a repeated-measures analysis of variance. The p values for the comparisons between ewes and twins were similarly adjusted. Recovery is reported as units per deciliter assayed per units per kilogram infused. Volume of distribution $\left(\mathrm{V}_{\mathrm{d}}\right)$ and clearance $(\mathrm{Cl})$ are reported as deciliters per kilogram and deciliters per kilogram per hour, respectively. A p value of $<0.05$ was considered statistically significant. Singleton and twin gestations were analyzed separately for all calculations.

\section{Results}

Three ewes and 4 singleton fetuses were infused with AT, while PC was administered to 6 ewes, 4 singleton fetuses and 3 pairs of twin fetuses. The pharmacokinetic properties of human AT and PC were statistically significantly different in the ewe compared with the fetus (table 1). In order to confirm that the distribution of the proteins was confined to the animal to which the infusion was administered, we sampled the fetus following maternal infusions and sampled the ewe following fetal infusions. We were unable to detect transfer of the proteins from ewe to fetus or from fetus to ewe.

The recovery of both PC and AT among ewes was approximately double that of singleton fetuses $(p<0.0001$ for both infusates). As expected, the $V_{d}$ in ewes was roughly half of the $\mathrm{V}_{\mathrm{d}}$ in singleton fetuses (AT: $\mathrm{p}<0.0001$, $P C: p=0.0002)$. The $\mathrm{Cl}$ was markedly lower in the ewes compared to the fetuses (AT: $\mathrm{p}<0.0001, \mathrm{PC}: \mathrm{p}=0.004$ ). Differences between ewes and fetuses in the AT and PC concentrations $15 \mathrm{~min}$ following the infusion $\left(\mathrm{Cp}_{0}\right)$ were not tested, because these values are dose dependent, and doses were inconsistent across animals. The fetuses required a weight-specific dose ranging from 2 to nearly 3 times that of the ewe in order to achieve a similar plasma concentration 15 min following the end of the infusion.

AT distribution and elimination curves for each ewe and fetus are shown in figure 1 . The $t_{1 / 2}$ of AT in the ewes was $18.7 \mathrm{~h}$ (95\% CI: 11.6-25.8); among the fetuses, the $t_{1 / 2}$ was $5.5 \mathrm{~h}$ (95\% CI: 4.01-7.08). PC distribution and elimination curves for each ewe and fetus are shown in figure 2. Although the curves for PC differ from those for AT and suggest different patterns of distribution and elimination, the overall results are similar. Among the ewes, the average recovery was $3.1 \mathrm{U} / \mathrm{dl}$ per $\mathrm{U} / \mathrm{kg}$ (range: $2.6-$ 3.3), while it was only $1.4 \mathrm{U} / \mathrm{dl}$ per $\mathrm{U} / \mathrm{kg}$ for the fetuses (range: 1.1-1.8). The $t_{1 / 2}$ of PC also was statistically sig- 
Fig. 2. Elimination of human $\mathrm{PC}$ in ewes and fetal lambs. Each solid line represents the plasma concentration of PC for a ewe. The open circles and open triangles indicate doses of 30 and $50 \mathrm{U} / \mathrm{kg}$, respectively. All other ewes received a dose of $25 \mathrm{U} / \mathrm{kg}$. The black and grey dashed lines represent singleton and twin fetuses, respectively. The closed circles indicate a dose of $50 \mathrm{U} /$ $\mathrm{kg}$; all other fetuses were administered a dose of 70 or $71 \mathrm{U} / \mathrm{kg}$. The inset graph uses the same scheme to show the natural logarithm of the plasma concentration of PC. Doses are not depicted on the inset graph.

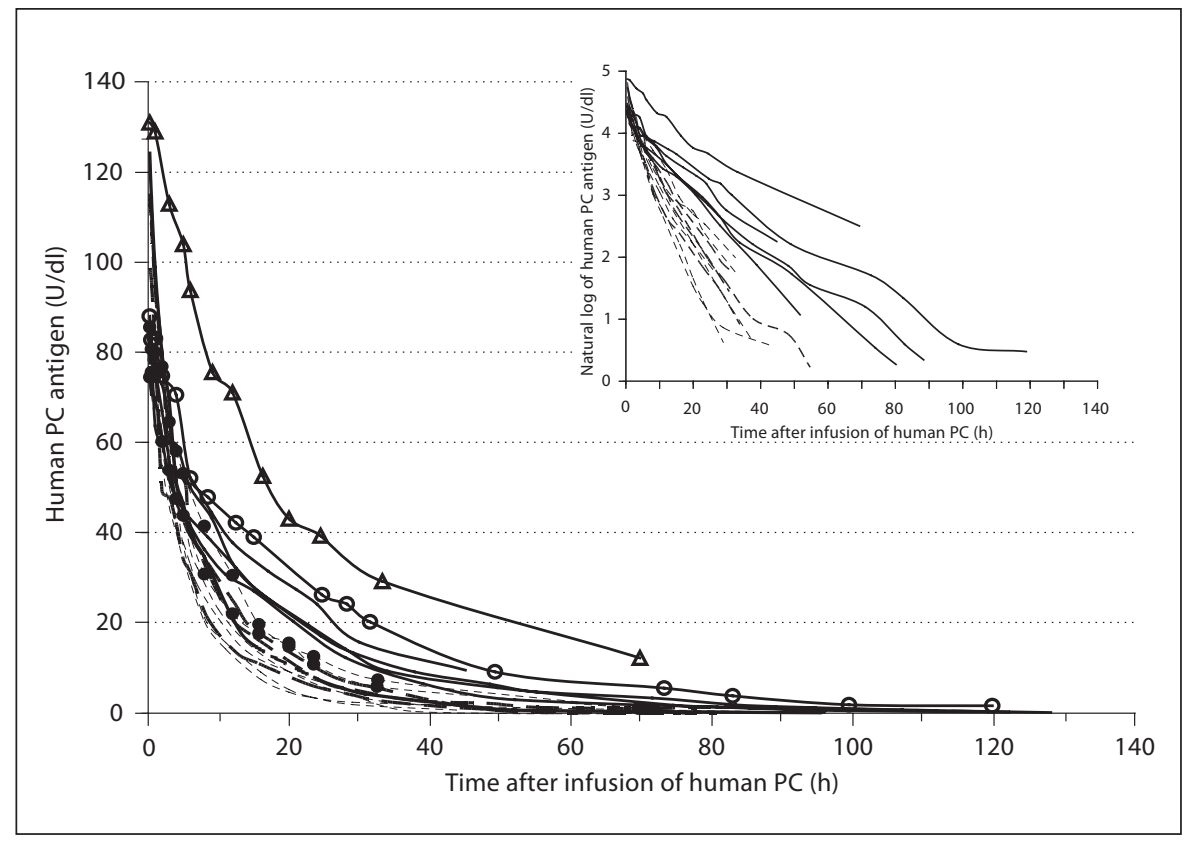

nificantly longer in the ewes (11.9 h; 95\% CI: 10.9-12.9) than in both singleton and twin fetuses. In addition, the $\mathrm{t}_{1 / 2}$ of PC was significantly shorter in the singleton fetuses (3.86 h; 95\% CI: 3.35-4.36) compared with the twin fetuses (5.56 h; 95\% CI: 5.09-6.03).

\section{Discussion}

We employed a chronically catheterized ovine model to study the pharmacokinetics of the coagulation regulatory proteins AT and PC to better understand neonatal deficiency states and to plan data-driven preventive and therapeutic strategies. We previously reported that ovine $\mathrm{PC}$ and AT can be detected in plasma of fetal lambs at 70 days of gestation (term gestation is 147 days) [33]. In that study, AT plasma concentrations increased linearly with gestational age. In contrast, PC plasma concentration did not increase from midgestation to the neonatal period and decreased slightly during the second and third trimester of gestation. Further experiments suggested that plasma concentration of $\mathrm{PC}$ in the ovine fetus is not regulated at the level of gene transcription.

In the current study, plasma recovery and $t_{1 / 2}$ of human AT and PC in the fetal lamb were approximately onethird to one-half of the corresponding values in the ewe. These data are similar to plasma $t_{1 / 2}$ studies of ovine fibrinogen conducted in neonatal lambs in comparison to adult sheep [36]. Our data support both increased dose and dose frequency for replacement of AT or PC newborn infants relative to dosing in adults.

Very few data exist regarding pharmacokinetics of coagulation PC concentrates in newborn infants. Two reports of neonatal treatment of genetic PC deficiency with human plasma-derived PC concentrates describe an initial $t_{1 / 2}$ of $2-3 \mathrm{~h}$, similar to results found in our fetal-maternal ovine model $[37,38]$. In both of these reports, apparent $P C t_{1 / 2}$ extended to $10 \mathrm{~h}$ with continued treatment. Our studies did not include repeated dosing to determine whether ovine plasma elimination would be decreased with saturation of a possible reservoir compartment. Interestingly, 2 recent case reports of newborn infants with hemophilia B infused with recombinant factor IX have described extraordinarily high dosing requirements to maintain adult hemostatic plasma factor IX concentrations $[39,40]$. In these 2 cases, factor IX requirements decreased over the first 2-4 months of life despite absence of an inhibitory antibody to factor IX. Factor IX is like PC in that it is also a vitamin-K-dependent coagulation protein with a similar molecular weight and volume of distribution, and it is possible that the two proteins share developmental pharmacokinetics. In contrast, infused factor VIII remains limited to the plasma compartment and has been reported to have a $t_{1 / 2}$ only modestly reduced from $12 \mathrm{~h}$ in healthy adults to 6 and $8 \mathrm{~h}$ in 2 preterm infants with hemophilia A [41]. 
It is evident that therapeutic armamentaria will continue to increase as more plasma protein replacements are available from recombinant and plasma-derived production. Consideration of replacement therapies for term and preterm infants with diagnosed coagulopathies will grow in parallel with expanded product availability. There exists a great need for pharmacokinetic data to guide coagulation protein replacement therapy in newborn infants. While the ovine model is limited in that data cannot be directly applied to human infants, ovine and other animal species can be employed to model developmental pharmacokinetics and to estimate comparative treatment dosing for human infants. At the same time, it is imperative to monitor plasma concentrations around coagulation protein dosing in human infants in order to estimate crude pharmacokinetic data ex vivo. Initial treatment for a newborn may use a loading dose of AT or PC concentrate of $80-100 \mathrm{U} / \mathrm{kg}$ with resultant plasma activity determined by a rapid chromogenic assay at $1 \mathrm{~h}$ and $6-8 \mathrm{~h}$ following the infusion. The data would be used to calculate subsequent doses adequate to maintain a trough level of $30 \%$ or greater.

\section{Acknowledgement}

Supported by grants: National Institutes of Health, HL44586, and the American Diabetes Association (M.M.J.); and National Institutes of Health, DK35836 and HD20761 (W.W.H.).

\section{References}

1 Journeycake JM, Manco-Johnson MJ: Thrombosis during infancy and childhood: what we know and what we do not know. Hematol Oncol Clin North Am 2004;18:13151319.

2 Manco-Johnson MJ: Pathophysiology of neonatal disseminated intravascular coagulation and thrombosis; in Polin RA, Fox WW (eds): Fetal and Neonatal Physiology. Philadelphia, Saunders, 2002.

$\checkmark 3$ Andrew M, Paes B, Johnston M: Develop ment of the hemostatic system in the neonate and young infant. Am J Pediatr Hematol Oncol 1990;12:95-104.

4 Manco-Johnson MJ: Development of hemostasis in the fetus. Thromb Res 2005;115 (suppl 1):55-63.

5 Manco-Johnson MJ, Marlar RA, Jacobson LJ, Hays T, Warady BA: Severe protein C deficiency in newborn infants. J Pediatr 1988; 113:359-363

-6 Manco-Johnson MJ, Abshire TC, Jacobson LJ, Marlar RA: Severe neonatal protein C deficiency: prevalence and thrombotic risk. J Pediatr 1991;119:793-798

$\checkmark 7$ McDonald MM, Jacobson LJ, Hay WW Jr, Hathaway WE. Heparin clearance in the newborn. Pediatr Res 1981;15:1015-1018.

8 McDonald MM, Hathaway WE: Anticoagulant therapy by continuous heparinization in newborn and older infants. J Pediatr 1982; 101:451-457.

-9 Roman K, Rosenthal E, Razavi R: Pulmonary arterial thrombosis in a neonate with homozygous deficiency of antithrombin III: successful outcome following pulmonary thrombectomy and infusions of antithrombin III concentrate. Cardiol Young 2000;10: 275-278.
10 Sanchez J, Velasco F, Alvarez R, Roman J, Torres A: Aortic thrombosis in a neonate with hereditary antithrombin III deficiency: successful outcome with thrombolytic and replacement treatment. Acta Paediatr 1996; 85:245-247.

11 Seguin J, Weatherstone K, Nankervis C: Inherited antithrombin III deficiency in the neonate. Arch Pediatr Adolesc Med 1994; 148:389-393.

12 Petaja J, Peltola K, Rautiainen P: Disappearance of symptomatic venous thrombosis after neonatal cardiac operations during antithrombin III substitution. J Thorac Cardiovasc Surg 1999;118:955-956.

13 Shapiro A: Antithrombin deficiency in special clinical syndromes. I. Neonatal and pediatric/physiologic deficiency: extracorporeal membrane oxygenation. Semin Hematol 1995;32:33-36.

14 Ishiguro K, Kojima T, Kadomatsu K, Nakayama Y, Takagi A, Suzuki M, Takeda N, Ito M, Yamamoto K, Matsushita T, Kusugami K, Muramatsu T, Saito H: Complete antithrombin deficiency in mice results in embryonic lethality. J Clin Invest 2000;106:873-878.

15 Menache D, O’Malley JP, Schorr JB, Wagner B, Williams C; and the Cooperative Study Group: Alving BM, Ballard JO, Goodnight SH, Hathaway WE, Hultin MB, Kitchens CS Lessner HE, Maltary AZ, Manco-Johnson M, McGehee WG, Penner JA, Sanders JE: Evaluation of the safety, recovery, half-life, and clinical efficacy of antithrombin III (human) in patients with hereditary antithrombin III deficiency. Blood 1990;75:33-39.
16 Inomoto T, Takamoto M, Tamura R, Maegawa M, Kamada M, Takayanagi M: Effective prophylaxis of thrombosis by antithrombin III concentrate in a pregnant woman with congenital antithrombin III deficiency: relations between plasma antithrombin III activity and the plasma levels of hemostatic molecular markers. Haemostasis 1991;21: 147-154.

17 Shiozaki A, Arai T, Izumi R, Niiya K, Sakuragawa N: Congenital antithrombin III deficient neonate treated with antithrombin III concentrates. Thromb Res 1993;70:211216.

18 Coccheri S, Palareti G: Antithrombin III replacement in orthotopic liver transplantation. Semin Thromb Hemost 1993;19:268272 .

19 Mitchell L, Andrew M, Hanna K, Abshire T, Halton J, Wu J, Anderson R, Cherrick I, Desai S, Mahoney D, McCusker P, Chait P, Abdolell M, de VG, Mikulis D: Trend to efficacy and safety using antithrombin concentrate in prevention of thrombosis in children receiving L-asparaginase for acute lymphoblastic leukemia. Results of the PAARKA study. Thromb Haemost 2003;90:235-244.

20 Munteanu C, Bloodworth LL, Korn TH: Antithrombin concentrate with plasma exchange in purpura fulminans. Pediatr Crit Care Med 2000;1:84-87.

21 Nowak-Gottl U, Groll A, Kreuz WD, Brand M, Breddin HK, von Lowevenich V, Kornhuber B: Treatment of disseminated intravascular coagulation with antithrombin III concentrate in children with verified infection (in German). Klin Pädiatr 1992;204: 134-140.

-22 Andrew M, Vegh P, Johnston M, Bowker J, Ofosu F, Mitchell L: Maturation of the hemostatic system during childhood. Blood 1992; 80:1998-2005. 
23 McDonald MM, Johnson ML, Rumack CM, Koops BL, Guggenheim MA, Babb C, Hathaway WE: Role of coagulopathy in newborn intracranial hemorrhage. Pediatrics 1984;74: 26-31.

-24 Branson HE, Katz J, Marble R, Griffin JH: Inherited protein $\mathrm{C}$ deficiency and coumarin-responsive chronic relapsing purpura fulminans in a newborn infant. Lancet 1983;ii:1165-1168.

-25 Hartman KR, Manco-Johnson M, Rawlings JS, Bower DJ, Marlar RA: Homozygous protein C deficiency: early treatment with warfarin. Am J Pediatr Hematol Oncol 1989;11: 395-401.

-26 Marlar RA, Montgomery RR, Broekmans AW: Diagnosis and treatment of homozygous protein $\mathrm{C}$ deficiency. Report of the Working Party on Homozygous Protein C Deficiency of the Subcommittee on Protein $\mathrm{C}$ and Protein S, International Committee on Thrombosis and Haemostasis. J Pediatr 1989; 114:528-534.

-27 Manco-Johnson M, Nuss R: Protein C concentrate prevents peripartum thrombosis. Am J Hematol 1992;40:69-70.

-28 Zimbelman J, Lefkowitz J, Schaeffer C, Hays T, Manco-Johnson M, Manhalter C, Nuss R: Unusual complications of warfarin therapy: skin necrosis and priapism. J Pediatr 2000; 137:266-268.
29 Dreyfus M, Magny JF, Bridey F, Schwarz HP, Planche C, Dehan M, Tchernia G: Treatment of homozygous protein $\mathrm{C}$ deficiency and neonatal purpura fulminans with a purified protein C concentrate. N Engl J Med 1991; 325:1565-1568.

30 Nardi M, Karpatkin M: Prothrombin and protein $\mathrm{C}$ in early childhood: normal adult levels are not achieved until the fourth year of life. J Pediatr 1986;109:843-845.

31 Manco-Johnson MJ, Carver T, Jacobson LJ, Townsend SF, Hay WW Jr: Hyperglycemiainduced hyperinsulinemia decreases maternal and fetal plasma protein $\mathrm{C}$ concentration during ovine gestation. Pediatr Res 1994;36: 293-299.

32 Manco-Johnson MJ, Spedale S, Peters M, Townsend SF, Jacobson LJ, Christian J, Krugman SD, Hay WW Jr, Sparks JW: Identification of a unique form of protein $\mathrm{C}$ in the ovine fetus: developmentally linked transition to the adult form. Pediatr Res 1995;37: 365-372.

33 Manco-Johnson MJ, Jacobson LJ, Hacker MR, Townsend SF, Murphy J, Hay W Jr: Development of coagulation regulatory proteins in the fetal and neonatal lamb. Pediatr Res 2002;52:580-588.

34 Creasy RK, Drost M, Green MV, Morris JA: Determination of fetal, placental and neonatal blood volumes in the sheep. Circ Res 1970;27:487-494.
35 Loughnan PM, Sitar DS, Ogilvie RI, Neims AH: The two-compartment open-system kinetic model: a review of its clinical implications and applications. J Pediatr 1976;88: 869-873.

36 Andrew M, Mitchell L, Berry LR, Schmidt B, Hatton MW: Fibrinogen has a rapid turnover in the healthy newborn lamb. Pediatr Res 1988;23:249-252.

-37 Dreyfus M, Masterson M, David M, Rivard GE, Muller FM, Kreuz W, Beeg T, Minford A, Allgrove J, Cohen JD: Replacement therapy with a monoclonal antibody purified protein $\mathrm{C}$ concentrate in newborns with severe congenital protein C deficiency. Semin Thromb Hemost 1995;21:371-381.

38 Baliga V, Thwaites R, Tillyer ML, Minford A, Parapia L, Allgrove J: Homozygous protein C deficiency - management with protein $\mathrm{C}$ concentrate. Eur J Pediatr 1995;154:534538.

39 Guilcher GM, Scully MF, Harvey M, Hand JP: Treatment of intracranial and extracranial haemorrhages in a neonate with severe haemophilia B with recombinant factor IX infusion. Haemophilia 2005;11:411-414.

40 Douvas MG, Monahan PE: Life-threatening thrombosis complicating the management of hepatic hemorrhage: anticoagulant treatment in a newborn with hemophilia B. J Pediatr Hematol Oncol 2004;26:258-263.

-41 Bidlingmaier C, Bergmann F, Kurnik K: Haemophilia A in two premature infants. Eur J Pediatr 2005; 164:70-72. 